\title{
ASSISTANCE OF PEASANTS IN LITHUANIA AT THE TURN OF THE CENTURY
}

\author{
Jonas MARDOSA \\ 2022 Vilnius, Zemynas 33-36, Lithuania
}

\begin{abstract}
'TALKA' (Voluntary unpaid work performed collectively) is a form of work organization based on mutual help from neighbours and working in return. The area where this form of assistance is spread over is rather large. This form of work is common not only to Lithuanians, (in Lithuanian it is called 'TALKA'), but also in Russia and Ukraine (where it is called 'TOLOKA') in Byelorussia ('TALAKA'), in Poland ('TŁOKA'). However, in each nation it has its own peculiarities. The basic purpose of this kind of assistance is to do urgent work of a greater volume, in which case the peasant and his family members are not sufficient or the nature of the work demands a greater number of farm-hands. Therefore 'talka' directly relates to the development of peasant farming. As far back as the end of the 19th century, as the use of threshers spread throughout the Lithuanian villages and they needed to be worked by quite a number of hands, the assistance while threshing (külimo talka) which earlier was not considered a prominent tradition, became a popular practice, especially on medium or large farms that were under an obligation to thresh a large quantity of corn (grain). So 'Talka' is not only the remnant of the primitive society work tradition, but also the outcome of the property and social differentiation among peasants.

At the end of the 19th century, as large peasant farms were taking shape, the property differentiation which was becoming more obvious brought in new traits to 'TALKA'. According to the way it was organized, 2 types of the assistance work (Talka) could be segregated. First of all Work-in-Return Assistance (Atodirbines talkos) came to flourish. (The Russians used to call this kind of work just 'Work in Return' (ZELENIN 1991). (Paying by Work). This was the kind of assistance which some peasants came to in the hope of receiving support for themselves (work in return), while others used to work off their debts; i.e. for the seed, pasturing, meadows, etc. After WW1, however, besides the peasants, hired hands used to participate in the 'Talka'. This form of assistance is more typical of harvest time, time of fertilizing fields, hay-making and forest care. This principle of organizing 'Talka' became practiced among peasants through the manor, where the "work-in-return" practice in the post-serfdom period village (serfdom in Lithuania went out of practice in the 7 th decade of the 19th century) was a remnant of the Serfdom Law, therefore "workin-return" practice in the manors might be classified as a modification of the feudal
\end{abstract}


farming assistance. Having lost its obligatory assistance (prievolines talkos) the manor found a way out: making use of its material superiority, over the majority of peasants, it forced peasants to work off their debts. Through a strong argument which made peasants do the asistance work, the farming lands were damaged and trampled, which happened due to the configuration complexity of the peasants' plots of land. This kind of "work-in-return" did not spread all over Lithuania and its extent was growing less than the capitalist system being developed (VANSEVIČIUS 1957), for the reason of the property differentiation in a new form and on a new basis worked its way into the area of peasants' interrelation. But such shared work was called 'Talka' (voluntary unpaid assistance), because what it carried was the traits of the "work-in-return" assistance. Also, another circumstance allows to call it 'Talka'. The manors and the large peasant farms that had accepted this model of assistance, have kept the rituals typical of unpaid peasant assistance; for example: at the end of the harvest time a wreath used to be twined and harvest home was a tradition. The manors all chipped in and worked for a priest; for example: during the unpaid peasant assistance they made hay and dried it, while the farmers cut trees for firewood in winter and brought them.

The concentration of work-in-return assistance in major farms was often compulsory. Let us say, dried flax needs to be broken because it might grow damp. That is the reason why farmers could not do without farm-hands at the jobs that required many. In this case, the assistance accumulation was determined by the technology they used.

Hired hands were sent to the peasants who did the unpaid assistance work by the owner of a large farm; i.e. even in small farms this kind of assistance was performed by a mixed group of hands. There was probably another reason why work-inreturn assistance was growing in major farms. A peasant found it cheaper to invite other peasants to work in his own farm and send hired hands to work it off, rather than hire extra hands. Besides, due to a better diet, the harvest home hands were willing to do unpaid assistance work. So the work-in-return assistance at the turn of the century may be broken down into 4 categories:

(1) mixed unpaid assistance in large peasants' farms, where the family members and hired hands, as well as peasants who were working it off worked;

(2) the very own family (as well as hired hands) and those who did work in return;

(3) the family and the workers-in-return. The latter variant is typical of mediumsized farms;

(4) the kind of assistance that has some community work traits as to its organization - it is a time of flax-dressing, and later threshing, when a couple of peasants work it off to each other by agreement, that is, they go from door to door, doing work for each person that participated in the unpaid assistance work. These methods of organizing were well-known in Russia, the only difference being the fact that the very community arranged the assistance work that went from door to door (GROMYKO 1986) and in Lithuania it was done by a group of neighbours. There was, however, more common ground among these 4 work-in-return assistance types, and that was customs and rituals. 
While classifying the assistance work, there is no strong need for taking into consideration customs though, during this work, they are more discernible, more widely spread, more emphasized, but this is not its obligatory element. Besides the unpaid assistance work accompanied by numerous traditions there was such assistance work where the customs are absent. This depended on many factors: family traditions, the age of the assisting hands, their number, character, etc.

The second type of the assistance work as far as their concentration is concerned would be work based on voluntary help, i.e. one works not only to work it off, but also with a wish to help their neighbours. Working of assistance had a fixed "workin-return" model. The same number of people, days, etc. had to be present. It is voluntary work, when the assistance hand comes to your help invited or uninvited, but not for a fixed amount of work in return - they do not have a fixed pay, and the way it will be given is up to the owner: a feast, meat of an animal that has just been slaughtered or some other way. It would be incorrect to state, that there existed assistance work that they did without expecting any benefit for themselves. Even assistance to victims of fire, the sick, in case of death that they gave without watching the clock and without saving their energy which was an expression of extremely charitable help (sometimes this work did not even carry the name 'Talka') was based not only on ethnic criteria. None of the peasants were sure that they could avoid a similar disaster and then their unfriendly behaviour might bring about something that they least desired. It was typical that the assistance of the second type is normally organized so that the work could be completed sooner or they came having finished theirs. Latecomers (those who come in the afternoon) are not liked by anybody, for it is obvious that they come to the feast that was part and parcel of this kind of assistance works. Work in return is organized for the whole work, eg fertilizing fields, harvesting, flax-breaking. Though the assistance worker did not have to work the whole time the duration of work had to be fixed. Lithuanian ethnologist VYŠNIAUSKAITE states that assistance work should be the original one, a remnant from the primitive society times (VYŠNIAUSKAITÉ 1983: 147). However, this treatment of the matter is not accurate, as I have already mentioned, their help was rewarded. Both kinds of assistance work are based on the traditions of voluntary work. The second type of the assistance work might more rightly be called assistance based on an unfixed form of payment.

The assistance work of the primitive society has to do with enclosing common pastures with fences and road repair work. In the districts that woods grew in, and where people lived in lonely homesteads, there was a custom to put fences on the land's boundaries (BUTKEVIČIUS 1971). Fence-building and other jobs like building bridges, footbridges, draining marshes, the sequence of jobs was arranged, things were discussed at the village meetings, and the jobs were carried out by the whole village community.

The reseachers into the assistance work in western Lithuania have divided them into 2 types, when the assistance workers are: 1) just the relatives; 2) just the neighbours. In this way assistance work became not only mutual help, but also visiting, especially for the relatives living far away (NEZABITAUSKIS 1935). However, this 
division principle is not supported enough because such an occasion of assistance work in which simply the relatives, their own household, or neighbours participated did not exist. The company was normally mixed and the best part of it consisted of neighbours. In addition to that, relatives do not always live close by, inviting them is difficult, instead, they dealt with them in another way, not through assistance work.

Work is the purpose of voluntary unpaid assistance, that is why they are to be classified into primary groups: agricultural, cattle-raising according to the nature of work, house-building and various others.

Agricultural assistance work has to do with the most relevant jobs on a peasant's farm. These are ploughing, sowing, fertilizing fields, hay-making, swinging flax, threshing, planting potatoes and picking them. In this context we are able to make out 2 groups of assistance work. The first one - ploughing, sowing, potato-planting was compulsory and rather rare.

Peasants usually performed this work using their family members, and only in case a family member fell ill or died was a family made to ask for neighbours' help. Other cases of such assistance work are not common still, they were a constant phenomenon in the village. These are field-manuring, hay-making, flax-breaking, threshing, potato-picking.

Cattle-raising assistance work is not equally common, because not many jobs are connected with this trade. The most important job in the cattle-raising area seems to be pig slaughtering assistance work. There also existed the assistance work of washing and shearing sheep, cattle-castration, goose-plucking.

House-building assistance work might be subdivided into forest care and wood preparation, carrying of building material and timber, ramming of an oven and the threshing-floor.

Various assistance work: feather-splitting, making cabbage preserves (pickling), digging out peat, or very occasional work for exceptional cases (death, marriage, disease) - spinning, picking wool, flax hackling and similar jobs.

The Structure of the assistance work is complex, but its principle chart is as simple as it could be: invitation to work, work, harvest home. However, each of its structural elements has its own variants, that depend on the duration of the work as well as its social significance. E.g. manuring fields, harvesting, flax-breaking, threshing, sometimes picking potatoes used to be done on the scale of the whole village and even its surrounding areas. Normally the owners invited people to assistance work when the whole procedure of the work was fixed (if it was just women who worked, the inviter was the owner's wife). This is especially important when a fixed number of hands is obligatory at work, e.g. harvest at the thresher. In that case they invite workers several days in advance, and if the assistance work is done from door to door, or several neighbours worked at one bathhouse - then those interested agree upon it themselves. The hands could be invited the day before or just before starting the work to help whose beginning was determined by the convictions of the peasants or a special pick about the day had to be taken e.g. following the sky watch: cabbage-pickling, sheep-shearing, pig-slaughtering and the like). This kind of work did not last long. As I have pointed out, among close neighbours, relatives or friends 
there happened to be voluntary assistance work without any invitation. It is when one drops by to help after they have completed their work or when they have some spare time. This kind of assistance is not necessarily meant for the completion of work.

The Course of Work has 2 prominent course variants:

(1) When assistance work is done during the whole works: manuring fields, harvesting, flax-breaking, threshing, wood timber carrying (they worked 1-2 or even 3 days on that).

(2) Assistance work is done half a day or even shorter, i.e. for the end or a onetime job (pig-slaughtering or one of the stages on a job that took a long time (lifting of the truss [rafters in house building]).

We might call the work process of the first variant complete, i.e. assistance work includes work with its fixed beginning and end. This kind of work is always characteristic of Work-in-Return assistance. One or two of these qualities are more easily seen with the help of traditions and rituals.

Rituals will mark not only the end of the work, but also give a hint to the owner about the coming of the last stage of the work - a feast.

The work process contains the following structural elements:

1) the food (meals) provided often depend on the duration and nature of the work: in winter or summer, in the daytime or in the evening, etc.

2) Actions with the purpose of relaxation; a) Entertainment; b) tricks, songs, and the like, while working (hay-making, harvesting, etc.).

3) Ritual actions the customs of the beginning and completion of work.

4) Emulation of hands at work.

In the second variant in the Cause of Work they do not put special emphasis on the beginning and completion of work. Work has no festivity, but there also happen some customs (e.g. pig-slaughtering). This is quite common in the first variant. It may be giving a meaning to a ritual completion, e.g. after having lifted the truss, a wreath is put on it. The assistance work of this variant is usually not work-in-return, and in its essence, genetically, it comes close to Communal Work Organization. Besides, in this case, the work is not long in duration, there is not more than one break for a meal.

The third structural element of the assistance work is harvest home. It consists of:

a) ritual acts of the completion of the work - presentation of a wreath, sprinkling each other with water;

b) refreshments (a feast);

c) entertainment (a party).

The feast after the completion used to take place at any time when the work did not take long (the second variant of the work course) or after a while (e.g. treating the pig-slaughterers to a meal), as well as in the afternoon, in the evening or even at night when the work lasted all day or evening. The course and fun of the feast depended on the organizer of the assistance work (owner), his material (financial) status, the tradition of that particular village, the choice of the food, the personal qualities of the farm hands. 
Entertainment is a trait of the type of assistance work. In its form it is very close to a weekend party for the young. Parties used to be held at weekends and exceptionally, at other times. Entertainment either followed the feast (a meal) or took place in the middle of it. It followed the feast, the youth that did not chip in doing assistance work used to come, too. Such a course of completing assistance work acquired its status as a way of spending free time among the country youth.

Assistance work is collective peasant work, this is why its basic function - that of work determined the duration of the work, its content and structure. Assistance work is done collectively, that is why the merit of fostering traditions of collectivity is doubtless there. Still, the function of fostering a feeling of collectivity cannot be separated, because it is the feeling of collectivity that is the core of the assistance work - only in the case of a temporary body of workers will work be performed in a shorter period of time. However, collectivity, like charitable help, are moral categories. So, another function of assistance work might be bringing up virtues in people. To reveal them, work traditions lent them a hand. Working on his own farm and failing to do a good job a peasant will bring nothing but harm to his family. This kind of person is mocked by the whole village community and his social prestige is dubious, but his work does not concern other people's lives. Doing assistance work puts him in another situation. A worker doing a poor offhand job is the centre of attention and is to change attitude, otherwise he/she will not be invited to assistance work or will be asked to leave, in this way that worker will be left without helpers. The virtues of a person come to surface in his vernacular, his behaviour while working, at the table, during entertainment. Following the unanimously accepted behaviour code by the community led people to behave morally.

Customs is a factor regulating, stabilizing the life of the village community and its members, and ensuring youth socializing. The role of the customs in the people's lives made people foster the customs as well as bring people up in them. This was a matter of the whole community. Therefore customs and rituals practiced at work are numerous in number and, in addition, a requirement to follow them enables us to formulate the function of the custom-fostering. This is also witnessed by the fact that as the work customs in the 20th century were fading away, at the time of assistance work, they remain. Customs during the assistance work make a good change, especially if the work is monotonous, they give it some fun, relaxation. One more thing is that customs make not only farmers, but also the owner follow the existing code of the village way of life. Some of them had a provocative character, even an imperative goal. Let us say, twining harvest home wreath was a sign of the completion of the work and required a harvest home.

Verbal folk art (folklore) is closely intertwined with customs. Folklore elements abound at the time of work, relaxation, let alone harvest home. With young work participants it was a must to be able to dance, sing which was necessary in the collective work (atmosphere). As a result, assistance work aided in fostering verbal folklore (folk art) as well as putting it into practice. The same applies to feasting. The food served or even necessary for assistance work, especially its choice at feasts became the link through which the traditions of peasants' food and cooking festive 
meals survived. Still, feasting as an ingredient of assistanc work is to be analyzed as a potential element of a work festival. This opinion has been expressed by VYŠNIAUSKAITE், who agreed to the viewpoint of Finnish ethnologist VILKUNA that, for example, flax-breaking in the olden times could have been regarded as a work festival within the community (VYŠNIAUSKAITĖ 1983: 147). The feast, just like the customs, added festivity to assistance work, but still this was a reward for the work done, esp. in the case of 'non-work-in-return' assistance. Even at the working-off time it helped ensure to-be farm-hands for the future. The festivity of the work was also enriched by the country youth that did not do the assistance work, but who came over to dance during harvest home. It was the time when work grew into a festival of the country youth. However, this property is more characteristic of the thirties to fifties period. In the work assessment if we put festivity as something exceptional, work which proves to be the basic function of assistance work, would find itself in the second place.

Shared work is done quicker, especially if while working they emulate. The work of a peasant has a characteristic feature of individuality and it often comes separately from the activity of his family members. The youth was short of socializing, especially the hired hands were in need of it. It was made up for by assistance work that united different layers of society (e.g. with the help of this fact). Some might safely say, that assistance work in the country fulfilled the communicative functions.

Finally, in most elements of the assistance work its aesthetic function is displayed. The factors that influence it were the right preparation for work, the way of dressing - those of the owner and the participants, the state of the instruments brought to work, but above all, it was songs, dances, games. Elements of beauty and features of the aesthetic feeling exaltation are found in many parts of assistance work.

Undoubtedly, the functions of the assistance work listed above are closely intertwined; besides, this is typical not only of assistance work, but while doing it the work elements fulfilling this function are emphasized, made more obvious. That is why the assistance work in Lithuania at the turn of the century has a definite purpose - work, which in its essence is a quite complex economical, social and cultural phenomenon. At the time when peasants were getting private land and it became their personal farm, the scale of the assistance work decreased, the technology that was implemented in the farms of the well-off peasants quickened the work and their owners were able to do all the work by themselves. Whatever the farm and function of assistance work, it more or less has something to do with the village community, which under the feudal system was the very environment of a peasant's social and cultural life. The latter determined the creation and maintenance of the folk culture virtues, their handing-down from generation to generation (JURGINIS-LUKŠAITE 1981). The period we discussed is not linked to the feudal farm, still, its remnants in a person of a community prove to be quite influential (strong). The traditions of a community way of life are strong; they were maintained by living in a village and individual farming. However, as the material status of peasants increased, and as trade market farming came into use, assistant workers are replaced by people hired for piecework. 
Assistance work was most of all influenced by the individual-farm system that was dismantling community life, and eventually, the traditional assistance work was completely destroyed by the compulsory agricultural collectivization during the Soviet times, which took its basis apart.

\section{LITERATURE}

ZELENIN, D. K.

1991: Vostočnoslavianskaja etnografija. Moskva, p. 362.

VANSEVIČIUS, S

1957: Lietuvos valstiečių teisinè padėtis po 1861 m. reformos įvykdymo, Lietuvos valstiečiai 19 amžiuje. Vilnius, p. 215.

GROMYKO, M. M.

1986: Tradicionnyje normy provedenija i formy obščienya russkich krestjan 19 v. Moskva, p. 37. VYŠNIAUSKAITÉ, A.

1983: Lietuvių linininkystès papročiai, KUdIRKA, J., MILIUS, V., VYŠNIAUSKAITĖ, A., Valstiečių verslai. Iš lietuviu kultūros istorijos. T. 12, Vilnius, p. 147.

BUTKEVIČIUS, I.

1971: Lietuvos valstiečių gyvenviètės ir sodybos. Iš lietuvių kultūros istorijos. T. 6. Vilnius, p. 210. NEZABITAUSKIS, L.

1935: Talkos Žemaičiuose, Tautosakos darbai. Kaunas, T. 1, p. 113-114.

JURGINIS, J., LUKŠAITĖ, L.

1981: Lietuvos kultūros istorijos bruožai (Feodalizmo epocha. Iki aštuonioliktojo amžiaus). Vilnius, p. 199. 